\title{
LITERATURE REVIEW Cognitive-behavioral therapy for anxiety disorders in children and adolescents: a systematic review of follow-up studies
}

Terapia cognitivo-comportamental para transtornos de ansiedade na infância e adolescência: revisão sistemática de estudos de seguimento

Roberta Davis ${ }^{1,2}$, Maria Augusta Mansur de Souza', Roberta Rigatti ${ }^{3}$, Elizeth Heldt ${ }^{1,23}$

\begin{abstract}
Objective: To conduct a systematic review about the long-term response to cognitive-behavioral therapy (CBT) for anxiety disorders (ADs) in children and adolescents. Methods: The PubMed and ISI Web of Science databases were consulted. Search in the databases was performed in November 2012 and included cohort studies after CBT for ADs in children and adolescents with a follow-up period over 12 months. Results: A total of 10 papers met the inclusion criteria. The follow-up period ranged from 12 months to 13 years and the results generally showed maintenance of the short-term benefits with CBT. However, the studies presented limitations, especially regarding methods, such as lack of a control group and losses to follow-up. Conclusion: The long-term benefits of CBT were identified, however it would be interesting to conduct other studies with more frequent assessment periods, in order to minimize losses to follow-up, in addition to evaluating children and adolescents in the various stages of their development.
\end{abstract}

\section{RESUMO}

Objetivo: Realizar uma revisão sistemática sobre a resposta em longo prazo à terapia cognitivo-comportamental (TCC) para transtornos de ansiedade (TAs) em crianças e adolescentes. Métodos: Foram consultadas as bases PubMed e ISI Web of Science. A pesquisa nas bases de dados foi realizada em novembro de 2012 e incluíram-se estudos de coorte após TCC para TAs na infância e adolescência com período de seguimento superior a 12 meses. Resultados: Um total de 10 artigos preencheu os critérios de inclusão. O período de seguimento variou entre 12 meses e 13 anos e, em geral, os resultados indicaram a manutenção dos ganhos com a TCC em curto prazo. No entanto, os estudos apresentaram limitações, principalmente em relação ao método, como ausência de grupo controle e perdas de seguimento. Conclusão: Foram identificados os benefícios da TCC em longo prazo, porém seria interessante a realização de outros estudos que mantivessem períodos de avaliação mais frequentes a fim de minimizar perdas de seguimento, além de avaliar a criança e o adolescente nas diferentes etapas de seu desenvolvimento.

1 Federal University of Rio Grande do Sul (UFRGS), Postgraduate Program in Medical Sciences: Psychiatry, Brazil. 2 Hospital de Clínicas de Porto Alegre (HCPA), Anxiety Disorders Program, Brazil.

3 UFRGS, Nursing School; UFRGS, National Counsel of Technological and Scientific Development (CNPq), Undergraduate Research Program, Brazil.

2/19/2014

Approved in

$10 / 31 / 2014$ 


\section{INTRODUCTION}

Anxiety and fear are emotions inherent to human nature, which become pathological when they are disproportionate to the stimulus or qualitatively differ from that which is observed in a given age group ${ }^{1}$, characterizing anxiety disorders (ADs). These disorders are currently classified as: separation anxiety disorder (SepAD), panic disorder (PD), social anxiety disorder or social phobia (SAD), generalized anxiety disorder (GAD), specific phobia (SP), post-traumatic stress disorder (PTSD) and obsessive-compulsive disorder (OCD) ${ }^{2}$. A recent study observed that ADs are among the major disorders affecting children and adolescents, and up to $24.9 \%$ of them could experience these disorders over the course of their life ${ }^{3}$, with symptoms impairing their academic and social performance ${ }^{4}$.

Retrospective ${ }^{5}$ and prospective studies ${ }^{6-8}$ show that ADs in childhood and adolescence are chronic conditions that do not spontaneously present remission over time. If these disorders are not treated in their early stages, they increase the risk of school dropout or predict significant setbacks in academic life ${ }^{4}$, as well as psychopathologies in adulthood, such as depression ${ }^{6-11}$ and substance abuse ${ }^{12}$.

Despite its high prevalence and substantial associated morbidity, ADs in children and adolescents are still underdiagnosed and undertreated, even though there is evidence of effective treatment, such as pharmacotherapy ${ }^{13}$ and cognitive-behavioral therapy (CBT) ${ }^{14,15}$. In a meta-analysis involving 10 randomized controlled trials that compared CBT for ADs in childhood and adolescence with a waiting list, the remission rate in the CBT group was $56.5 \%$ versus $34.8 \%$ in the control group, suggesting a clinically significant benefit associated with the treatment ${ }^{16}$. In another meta-analysis, with 13 randomized clinical trials (498 patients and 311 controls), the response to CBT for any AD was $56 \%$, compared to $28.2 \%$ in the control group (RR: 0.6; Cl 95\%: 0.53-0.69), with a number needed to treat (NNT) of 3 (Cl 95\%: 2.5-4.5) $)^{17}$.

Follow-up studies evaluating long-term response to CBT are considerably more scarce when compared to studies evaluating short-term response. A recent review study about ADs showed that the short-term benefits of CBT are extended into late adolescence'. However, the authors suggest that more follow-up studies are needed in order to confirm the predictors of long-term results.

Considering these gaps, which are still observed in the literature, this study aims to carry out a systematic review of follow-up studies assessing CBT for ADs in children and adolescents.

\section{METHODS}

This is a systematic review, with queries to the PubMed and ISI Web of Science databases. As inclusion criteria, re- searchers looked for cohort studies after CBT for ADs in childhood and adolescence; in English, Spanish or Portuguese languages. There was no limitation regarding ADs types and publication date. Studies with a follow-up period under one year were excluded. The following search terms were used: "childhood"; "anxiety or anxiety disorders"; "cognitive behavioral therapy"; "follow-up".

Research in the databases and selection of the articles were conducted separately by two researchers. Studies mentioned in more than one database were computed only once. The abstracts of all the articles found in the search were preliminarily read; upon meeting the inclusion criteria, the entire article was read prior to its final inclusion.

In order to present the studys' findings, results with $p<$ 0.05 were considered as significant. Due to the heterogeneity of study designs (CBT format - individual or group; with or without parents) and variables (follow-up time), it was not feasible to conduct a meta-analysis of the studies included.

\section{RESULTS}

Search in the databases was conducted in November 2012 and 72 abstracts were found: 34 in PubMed (with eight selected to be read in full) and 38 in ISI Web of Science (with four selected to be read in full). A total of 10 articles met the inclusion criteria (Figure 1). Most studies that were excluded used follow-up periods of 3 to 6 months after CBT to reassess patients.

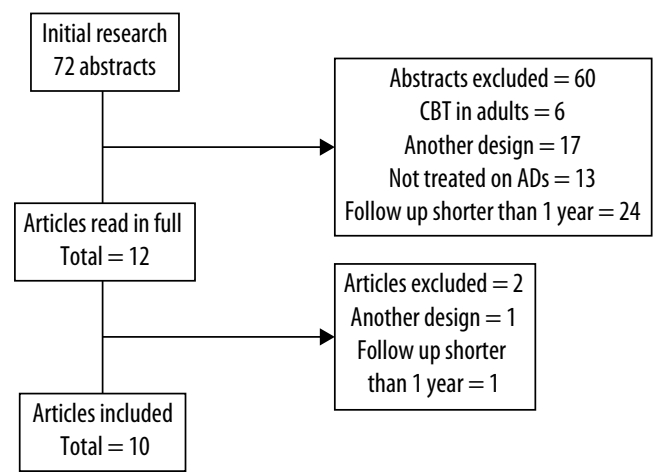

Figure 1. Flow chart of the study.

The characteristics and demographics of the studies included are shown in table 1. It can be observed that the follow-up period in the study ranged from 12 months to 13 years after CBT. Patients were diagnosed through instruments and 9 studies used the Anxiety Disorders Interview Schedule: Child Version (ADIS-C), which follows the criteria of the Diagnostic and Statistical Manual of Mental Disorders $(\mathrm{DSM})^{18-24,26,27}$. In addition to the ADIS, 7 articles used Child Behavior Checklist $(\mathrm{CBCL})$ completed by parents ${ }^{18-21,23,24,27}$. The four oldest studies were based on DSM-I||18-21. 
Table 1. Characteristics of the studies and follow-up sample

\begin{tabular}{|c|c|c|c|c|c|c|c|}
\hline \multirow[b]{2}{*}{ Studies* } & \multicolumn{2}{|r|}{ Intervention } & \multicolumn{5}{|c|}{ Follow-up** } \\
\hline & Protocol & Format & Time $^{\sharp}$ Mean (SD) & Total sample & 0 & $q$ & $\begin{array}{c}\mathrm{Age}^{*} \\
\operatorname{Mean}(\mathrm{SD})\end{array}$ \\
\hline Cobham et al., 2010 & CBT & GCBT x GCBT+ Parents & $\begin{array}{l}35 \text { and } 28 \text { months } \\
31.85(2.56)\end{array}$ & $60(89.6 \%)$ & 31 & 29 & $\begin{array}{c}10 \text { to } 17 \\
12.58(1.65)\end{array}$ \\
\hline Saavedra et al., 2010 & CBT & $\begin{array}{l}\text { GCBT x Individual (self control) x Individual } \\
\text { (contingency manegement) }\end{array}$ & $\begin{array}{l}8 \text { to } 13 \text { years } \\
9.83(1.71)\end{array}$ & $67(81 \%)$ & 35 & 32 & $\begin{array}{c}16 \text { to } 26 \\
19.43(3.02)\end{array}$ \\
\hline $\begin{array}{l}\text { 0'Leary; Barret; } \\
\text { Fjermestad, } 2009\end{array}$ & FOCUS & GCBT + Parents x CBT Individual + Parents & 7 years & $38(49 \%)$ & 20 & 18 & $\begin{array}{c}13 \text { to } 24 \\
18.4(2.85)\end{array}$ \\
\hline Bernstein et al., 2008 & FRIENDS & GCBT x GCBT + Parents x Waiting list & 1 year & $51(84 \%)$ & $\mathrm{NI}$ & $\mathrm{NI}$ & 8 to 12 \\
\hline Kendall et al., 2004 & Coping Cat & GCBT & $\begin{array}{l}5.5 \text { to } 9.3 \text { years } \\
\quad 7.4(\mathrm{NII})\end{array}$ & $85(90 \%)$ & 53 & 32 & $\begin{array}{l}15 \text { to } 22 \\
19.3(\mathrm{NI})\end{array}$ \\
\hline Manassis et al., 2004 & Coping Bear & Psychoeducation children x GCBT + Parents & 6 to 7 years & $43(68 \%)$ & 14 & 29 & $\begin{array}{l}14 \text { to } 19 \\
16.5(1.2)\end{array}$ \\
\hline Barret et al., 2001 & СВT & GCBT x GCBT+ Parents & $\begin{array}{l}5 \text { to } 7 \text { years } \\
6.2(\mathrm{NII})\end{array}$ & $52(67 \%)$ & 28 & 24 & $\begin{array}{c}13 \text { to } 21 \\
16.08(2.26)\end{array}$ \\
\hline $\begin{array}{l}\text { Cobham; Dadds; Spence, } \\
1998\end{array}$ & $\begin{array}{l}\text { Coping Cat } \\
\text { Coping Koala }\end{array}$ & GCBT x GCBT + Parents & 1 year & $\mathrm{NI}$ & $\mathrm{NI}$ & $\mathrm{NI}$ & 8 to 15 \\
\hline Barrett, 1998 & $\begin{array}{l}\text { Coping Cat } \\
\text { Coping Koala }\end{array}$ & GCBT x GCBT + Parents & 1 year & $\mathrm{NI}$ & $\mathrm{NI}$ & $\mathrm{NI}$ & 8 to 15 \\
\hline $\begin{array}{l}\text { Barrett; Dadds; Rapee, } \\
1996\end{array}$ & $\begin{array}{l}\text { Coping Cat } \\
\text { Coping Koala }\end{array}$ & GBTG x GBTG + Parents & 1 year & $\mathrm{NI}$ & $\mathrm{NI}$ & $\mathrm{NI}$ & 8 to 15 \\
\hline
\end{tabular}

CBT: cognitive-behavioral therapy; GCBT: group cognitive-behavioral therapy; NI: not informed.

* At the period of intervention, all studies had a randomized clinical trial design. ${ }^{* *}$ Follow-up studies without a control group, with the exception of Berstein et al., 2008. "Time of follow-up in months and age in years.

Among the scales used to assess the anxiety and depression symptoms, the most commonly used were the RevisedChildren Manifest Anxiety Scale (R-CMAS), the Multidimensional Anxiety Scale for Children (MASC) and the Children's Depression Inventory (CDI). Most follow-up interviews were conducted in person, but some took place by telephone or email. Patients were generally evaluated at the baseline (before starting (BT), after completing the sessions, within 3-6 months, and at the follow-up point, which ranged from 12 months to 13 years.

Regarding the format of the intervention, two studies compared individual CBT versus group CBT22,23. The remaining studies analyzed group CBT versus CBT including the family, with or without a waiting list. In the study of CBT for $O C D$, researchers compared individual CBT + family counseling to group CBT + family counseling ${ }^{22}$.

Three studies describe offering a reward in exchange for cooperation in the follow-up; in two studies this reward was monetary ${ }^{23,24}$ and, in another study, the reward consisted of movie tickets ${ }^{20}$. Additional treatment was after CBT deemed necessary in four studies ${ }^{21-25}$, taking place on an outpatient basis or even with hospitalization, and also with medication. Only in one study the participants who received additional therapy were excluded from the follow-up evaluation ${ }^{21}$.

The results of the follow-up studies after CBT regarding symptoms and diagnosis are presented in table 2. It is observed that, in most studies, the benefits of therapy regarding anxiety and depression symptoms were maintained over time; in three of them, improvement was greater at the follow-up ${ }^{18,20,23}$, in five there was an improvement compared to the baseline, but no significant difference regarding the evaluation after the end of the sessions ${ }^{19,21,24,26,27}$, and in two studies no difference in the anxiety symptoms was observed at the follow-up ${ }^{22,25}$.

It was also found that CBT can have a positive impact on the diagnosis of ADs over time, i.e., in eight of the studies, most patients no longer met the diagnostic criteria for the ADs, except in two studies, in which no significant difference was found ${ }^{25,26}$.

Out of the seven studies that included the family in therapy, four found significantly better results for CBT + family when compared to CBT only for the patients $18,20,26,27$ and in three of the studies the no difference was found in the results $19,21,25$.

These studies presented limitations, primarily in terms of method. For instance, most of them lacked a control group. Furthermore, the waiting list ended up receiving treatment, which rendered it useless as a control. Out of the ten studies, only one had a waiting list that was not treated; this was the only clinical trial with a controlled follow-up ${ }^{26}$. The lack of control for variables, such as the use of additional therapies, was also observed, which may indicate a bias in the interpretation of results. 
Table 2. The results of the follow-up studies after CBT regarding symptoms and diagnosis

\begin{tabular}{|c|c|c|c|c|}
\hline \multirow{2}{*}{ Studies* } & \multirow{2}{*}{ Diagnosis } & \multirow{2}{*}{ Instruments } & \multicolumn{2}{|c|}{ Follow-up outcomes } \\
\hline & & & Symptoms & Diagnosis \\
\hline Cobham et al., 2010 & Anxiety disorder & $\begin{array}{l}\text { ADIS-C } \\
\text { CBCL } \\
\text { RCMA-S }\end{array}$ & $\begin{array}{l}\text { Anxiety - significant improvement maintained, } \\
\text { compared to the baseline }\end{array}$ & $\begin{array}{l}\text { No longer met the criteria for the } \mathrm{Ads}=48(80 \%) \\
\text { There was significant difference between the } \\
\text { interventions: } \\
\mathrm{GCBT}-23(69 \%) \text { without a diagnosis of ADs } \\
\mathrm{GCBT}+\text { family - } 25(92 \%) \text { without a diagnosis } \\
\text { of ADs }\end{array}$ \\
\hline Saavedra et al., 2010 & $\begin{array}{l}\text { Social phobia } \\
\text { Specific phobia } \\
\text { Panic disorder/Agoraphobia } \\
\text { Depressive disorder }\end{array}$ & $\begin{array}{l}\text { ADIS-C \& ADIS-P } \\
\text { ADIS-IV } \\
\text { RCMA-S } \\
\text { MAS } \\
\text { CDI } \\
\text { BDI } \\
\text { CBCL } \\
\text { YASR }\end{array}$ & $\begin{array}{l}\text { Anxiety and depression symptoms - significant } \\
\text { improvement after } 1 \text { year of follow-up, } \\
\text { maintained up to } 9 \text { years after CBT }\end{array}$ & $\begin{array}{l}62(92.5 \%) \text { no longer met the criteria for the ADs } \\
61(91 \%) \text { did not meet the criteria for depression } \\
55(82.1 \%) \text { did not meet the criteria for any } \\
\text { disorder }\end{array}$ \\
\hline $\begin{array}{l}\text { 0'Leary; Barrett; } \\
\text { Fjermestad, } 2009\end{array}$ & $O C D$ & $\begin{array}{l}\text { ADIS -C \& ADIS-P } \\
\text { NIMH-GOCS } \\
\text { Y-BOCS-SR } \\
\text { MASC } \\
\text { MASC-OC } \\
\text { BDI-II } \\
\text { FAD } \\
\text { DASS-21 }\end{array}$ & $\begin{array}{l}\text { Anxiety - no significant improvement. } \\
\text { Depression symptoms - significant improvement } \\
\text { in individual CBT and in older individuals }\end{array}$ & $\begin{array}{l}\text { No diagnosis of OCD after } 7 \text { years of CBT }(87 \%) \\
\text { Individual CBT ( } 79 \%) \\
\text { GCBT }(95 \%)\end{array}$ \\
\hline Bernstein et al., 2008 & $\begin{array}{l}\text { Separation anxiety disorder } \\
\text { GAD } \\
\text { Social phobia }\end{array}$ & $\begin{array}{l}\text { ADIS } \\
\text { MASC } \\
\text { SCARED } \\
\text { CGI }\end{array}$ & $\begin{array}{l}\text { Anxiety - significant improvement when } \\
\text { compared to control group in } 6 \text { months of follow- } \\
\text { up, did not remain significant at } 12 \text { months }\end{array}$ & $\begin{array}{l}\text { No significant difference regarding the diagnosis } \\
\text { of ADs. CBT with training for parents appears to be } \\
\text { more effective than CBT only with the children }\end{array}$ \\
\hline Kendall et al., 2004 & $\begin{array}{l}\text { Primary } \\
\text { Anxiety disorder }\end{array}$ & $\begin{array}{l}\text { ADIS-C \& ADIS-P } \\
\text { ADIS-IV-L } \\
\text { CASI } \\
\text { RCMAS } \\
\text { CDI } \\
\text { CQ-C } \\
\text { APES } \\
\text { CBCL } \\
\text { CQ-P } \\
\text { STAIC }\end{array}$ & $\begin{array}{l}\text { Anxiety and depression symptoms - significant } \\
\text { improvement maintained, compared to the } \\
\text { baseline }\end{array}$ & $\begin{array}{l}\text { No longer met the criteria for the ADs: } \\
\text { After the CBT sessions }=51.2 \% \\
\text { At follow-up }=80.5 \%\end{array}$ \\
\hline Manassis et al., 2004 & $\begin{array}{l}\text { GAD } \\
\text { Others Anxiety Disorders }\end{array}$ & $\begin{array}{l}\text { DICA-R-P } \\
\text { RCMAS }\end{array}$ & $\begin{array}{l}\text { Anxiety and depression symptoms - persisted at } \\
\text { the follow-up, did not require clinical care in } 70 \% \\
\text { of the individuals treated }\end{array}$ & $\begin{array}{l}\text { No significant difference regarding the diagnosis } \\
\text { of ADs } \\
\text { Baseline ( } n=63): G A D=32(52 \%) \\
\text { Other ADs }=21(49 \%) \\
\text { Follow-up }(n=43): G A D=31(48 \%) \\
\text { Other ADs }=22(51 \%)\end{array}$ \\
\hline Barrett et al., 2001 & $\begin{array}{l}\text { Separation anxiety disorder } \\
\text { Social phobia } \\
\text { Simple phobia } \\
\text { Depression } \\
\text { Oppositional defiant disorder }\end{array}$ & $\begin{array}{l}\text { ADIS-C } \\
\text { RCMAS } \\
\text { FSSC-R } \\
\text { CDI } \\
\text { CBCL }\end{array}$ & $\begin{array}{l}\text { Anxiety and depression symptoms - significant } \\
\text { improvement maintained at 6-year follow up, } \\
\text { compared to the baseline, but greater than at the } \\
\text { 12-month evaluation }\end{array}$ & $\begin{array}{l}\text { No longer met the criteria for the ADs: } \\
\text { After } 12 \text { months }=79.6 \% \text { and after } 6 \text { years = } \\
85,7 \% \\
\text { CBT and CBT+FAM interventions were equally } \\
\text { effective }\end{array}$ \\
\hline $\begin{array}{l}\text { Cobham; Dadds; Spence, } \\
1998\end{array}$ & $\begin{array}{l}\text { GAD } \\
\text { Social phobia } \\
\text { Agoraphobia } \\
\text { Overanxious disorder } \\
\text { Separation anxiety disorder }\end{array}$ & $\begin{array}{l}\text { ADIS-C \& ADIS-P } \\
\text { RCMAS } \\
\text { STAIC } \\
\text { CBCL }\end{array}$ & $\begin{array}{l}\text { Anxiety - overall improvement observed in the } \\
\text { four conditions of treatment and significant } \\
\text { difference maintained, compared to the baseline }\end{array}$ & $\begin{array}{l}\text { No longer met the criteria for the ADs: } \\
C B T=82 \% \text { and } C B T+P A M=80 \%\end{array}$ \\
\hline Barrett, 1998 & $\begin{array}{l}\text { Separation anxiety disorder } \\
\text { Secondary diagnosis of } \\
\text { simple phobia } \\
\text { Depression }\end{array}$ & $\begin{array}{l}\text { ADIS-C \& ADIS-P } \\
\text { FSSC-R } \\
\text { CBCL }\end{array}$ & $\begin{array}{l}\text { Anxiety - significant improvement maintained } \\
\text { at follow-up }\end{array}$ & $\begin{array}{l}\text { No longer met the criteria for the ADs: } \\
\text { After CBT and CBT+FAM }=64.8 \% \text { versus } 25.2 \% \\
\text { waiting list } \\
\text { After } 12 \text { months: GCBT }=64.5 \% \text { versus } \\
\mathrm{GCBT}+\mathrm{FAM}=84.8 \% \\
\text { The intervention that included the family proved } \\
\text { more effective than GCBT only with the children }\end{array}$ \\
\hline
\end{tabular}


Table 2. The results of the follow-up studies after CBT regarding symptoms and diagnosis

\begin{tabular}{|c|c|c|c|c|}
\hline \multirow{2}{*}{ Studies* } & \multirow{2}{*}{ Diagnosis } & \multirow{2}{*}{ Instruments } & \multicolumn{2}{|c|}{ Follow-up outcomes } \\
\hline & & & Symptoms & Diagnosis \\
\hline $\begin{array}{l}\text { Barrett; Dadds; Rapee, } \\
1996\end{array}$ & $\begin{array}{l}\text { Overanxiety disorder } \\
\text { Separation Anxiety disorder } \\
\text { Social phobia }\end{array}$ & $\begin{array}{l}\text { ADIS-C \& ADIS-P } \\
\text { RCMAS } \\
\text { FSSC-R } \\
\text { CDI } \\
\text { CBCL } \\
\text { DASS } \\
\text { FEAR }\end{array}$ & $\begin{array}{l}\text { Anxiety and depression symptoms - overall } \\
\text { improvement observed in the three conditions of } \\
\text { treatment and significant difference maintained } \\
\text { at follow-up, compared to the baseline }\end{array}$ & $\begin{array}{l}\text { No longer met the criteria for the ADs: } \\
\text { After } 12 \text { months }=70.3 \% \text { of CBT versus } 95.6 \% \text { of } \\
\text { CBT+FAM } \\
\text { Both interventions maintained long-term } \\
\text { benefits, but there were additional clinical } \\
\text { benefits for CBT+FAM }\end{array}$ \\
\hline
\end{tabular}

ADs: anxiety disorders; OCD: obsessive-compulsive disorder; GAD: generalized anxiety disorder; CBT: cognitive-behavioral therapy; GCBT: Group Cognitive-Behavioral Therapy; PAM: Parental Anxiety Management, FAM: Family Management; ADIS-C \& ADIS-P: Anxiety Disorder Interview Schedule for DSM-IV, Child Version and Parent Version; ADIS-IVL: Anxiety Disorders Interview Schedule for DSM-IV, Lifetime; CASI: Comprehensive Adolescent Severity Inventory; RCMAS: Revised Children's Manifest Anxiety Scale; CDI: Children's Depression Inventory; CQ-C: Coping Questionnaire - Child; APES: Adolescent Perceived Events Scale; CBCL: Child Behavior Checklist; CQ-P: Coping Questionnaire - Parent; STAIC: State - Trait Anxiety Inventory for Children; FSSC-R: Fear Survey Schedule for Children - Revised; NIMH-GOCS: National Institute of Mental Health Global Obsessive-Compulsive Scale; Y-BOCS-SR: Yale Brown Obsessive Compulsive Scale-SR; MASC: The Multidimensional Anxiety Scale for Children; MASC-OC: The Multidimensional Anxiety Scale - Obsessive Compulsive Screen; BDI-II: Beck Depression Inventory-II; FAD: McMaster Family Assessment Device; DASS-21: Depression Anxiety Stress Scale-21; MAS: Taylor Manifest Anxiety Scale; YASR: Young Adult Self Report; DICA-R-P: Diagnostic Interview for Children and Adolescents Revised-Parent; FEAR: Family Enhancement of Avoidant Responses; SCARED: Screen for Child Anxiety-Related Emotion al Disorders; MASC: Multidimensional Anxiety Scale for Children; CGI: Clinical Global Impressions.

Only one study describes the use of additional therapies as an exclusion criterion ${ }^{21}$. Three other studies have described the use of additional therapies, but maintained the patients in the follow-up evaluation 20,24,25.

\section{DISCUSSION}

This review was conducted with scientific rigor and it has confirmed that there are very few follow-up studies of CBT for ADs in children and adolescents covering a period over 12 months. The main finding of the studies included is that the benefits of therapy are maintained over time, even for the cases in which the difference was in relation to the baseline $19,21,24,26,27$

Among the studies that compared CBT + Family and CBT only with the children, the results of more recent studies found that interventions including the family were more favorable ${ }^{26,27}$. On the other hand, in two studies, no differences was found between the groups, even though these are older studies ${ }^{19,21}$.

Losses to follow-up studies are another common limitation that may somehow compromise the results. This confirms the need for evaluations with shorter intervals and for the consideration of rewarding participants, as three studies in this review have done $20,23,24$.

In all the studies, there was a clear focus on clinical outcomes, such as the severity of symptoms and the maintenance of the diagnosis of AD at follow-up. Therefore, studies that focus on evaluating psychosocial aspects, such as school performance and quality of life over time, still need to be conducted. These other parameters say much about the functioning of children and adolescents, including the way they feel about themselves, the environments to which they are exposed and how satisfied they are with their lives. Also, considering that one of the goals of $A D$ treatment is to reduce the risk of psychopathology in adulthood, follow-up studies to define response predictors are yet to be developed'.

Some limitations of this study must be considered. The search was carried out on only two databases, and might, therefore, have left some studies aside, leading to more limited conclusions. Besides, the lack of long term follow-up studies makes it difficult to establish comparisons.

\section{CONCLUSIONS}

Despite these limitations, the long-term benefits of CBT were identified, regardless of whether the format was individual or in group, with or without the inclusion of the family. It would be interesting to conduct further studies that used more frequent evaluation intervals, in order to minimize losses to follow-up, in addition to evaluating children and adolescents in the different stages of their development.

\section{INDIVIDUAL CONTRIBUTIONS}

Roberta Davis - Planning, review of literature, reading of selected articles and writing of the manuscript.

Maria Augusta Mansur de Souza - Reading of selected articles, and critical review of the manuscript.

Roberta Rigatti - Review of literature, and critical review of the manuscript.

Elizeth Heldt - Planning and supervising all phases of research and critical review of the manuscript.

All authors approved the final version of the article.

\section{CONFLICTS OF INTEREST}

The authors have no conflicts of interest to be declared. 


\section{ACKNOWLEDGEMENTS}

Hospital de Clínicas de Porto Alegre (HCPA), where the Program of Anxiety Disorders in Childhood and Adolescence (PROTAIA) is developed and where the design and development of studies like this one takes place; the Federal University of Rio Grande do Sul (UFRGS), institution of origin of the authors.

\section{REFERENCES}

1. Nevo GA, Manassis K. Outcomes for treated anxious children: a critical review of LongTerm-Follow-Up studies. Depress Anxiety. 2009;26(7):650-60.

2. American Psychiatric Association e Manual Diagnóstico e Estatístico de Transtornos Mentais: revisão. 4.ed. Porto Alegre: APA; 2000.

3. Kessler RC, Avenevoli S, Costello EJ, Georgiades K, Green JG, Gruber MJ, et al. Prevalence, persistence, and sociodemographic correlates of DSM-IV disorders in the National Comorbidity Survey Replication Adolescent Supplement. Arch Gen Psychiatry. 2012;69(4):372-80.

4. Duchesne S, Vitaro F, Larose S, Tremblay RE. Trajectories of anxiety during elementary-school years and the prediction of high school noncompletion. J Youth Adolesc. 2008:37(9):1134-46.

5. Pollack MH, Otto MW, Sabatino S, Majcher D, Worthington JJ, McArdle ET, et al. Relationship of childhood anxiety to adult panic disorder: Correlates and influence on course. Am J Psychiatry. 1996;153(3):376-81.

6. Beesdo K, Bittner A, Pine DS, Stein MB, Höfler M, Lieb R, et al. Incidence of social anxiety disorder and the consistent risk for secondary depression in the first three decades of life. Arch Gen Psychiatry. 2007;64(8):903-12.

7. Bittner A, Egger HL, Erkanli A, Costello J, Foley DL, Angold A. What do childhood anxiety disorders predict? J Child Psychol Psychiatry. 2007;48(12):1174-83.

8. Moffitt TE, Harrington H, Caspi A, Kim-Cohen J, Goldberg D, Gregory AM, et al. Depression and generalized anxiety disorder: cumulative and sequential comorbidity in a birth cohort followed prospectively to age 32 years. Arch Gen Psychiatry. 2007;64(6):651-60.

9. Flannery-Schroeder EC. Reducing anxiety to prevent depression. Am J Prev Medicine. 2006;31(6):136-42.

10. Copeland WE, Shanahan L, Costello J, Angold A. Childhood and adolescent psychiatric disorders as predictors of young adult disorders. Arch Gen Psychiatry. 2009;66(7):764-72.

11. Beesdo K, Pine DS, Lieb R, Wittchen HU. Incidence and risk patterns of anxiety and depressive disorders and categorization of generalized anxiety disorder. Arch Gen Psychiatry. 2010;67(1):47-57.
12. Kendall PC, Kessler RC. The impact of childhood psychopathology interventions on subsequent substance abuse: Policy comments, and recommendations. J Consult Clin Psychol. 2002:70(6):1303-6.

13. Walkup JD, Albano AM, Piacentini J, Birmaher B, Compton SN, Sherrill JT, et al. Cognitive behavioral therapy, sertraline, or a combination in childhood anxiety. New England J Medicine. 2008;359(26):2753-66.

14. In-Albon T, Schneider S. Psychotherapy of childhood anxiety disorders: a meta-analysis. Psychother Psychosom. 2007;76(1):15-24.

15. Silverman WK, Pina AA, Viswesvaran C. Evidence-based psychosocial treatments for phobic and anxiety disorders in children and adolescents. J Clin Child Adolesc Psychol. 2008:37(1):105-30.

16. Cartwright-Hatton S, Roberts C, Chitsabesan P, Fothergill C, Harrington R. Systematic review of the efficacy of cognitive behavior therapies for childhood and adolescent anxiety disorders. British J Clin Psychol. 2004;43(4):421-36.

17. James A, Soler A, Weatherall R. Cognitive behavioural therapy for anxiety disorders in children and adolescents. Cochrane Database Syst Rev. 2009;19(4).

18. Barrett PM, Dadds MR, Rapee RM. Family treatment of childhood anxiety: a controlled trial. J Consult Clin Psychol. 1996;64(2):333-42.

19. Cobham VE, Dadds MR, Spence SH. The role of parental anxiety in the treatment of childhood anxiety. J Consult Clin Psychol. 1998;66(6):893-905.

20. Barrett PM. Evaluation of cognitive-behavioral group treatments for childhood anxiety disorders. J Clin Child Psychol. 1998;27(4):459-68.

21. Barrett PM, Duffy AL, Dadds MR, Rapee RM. Cognitive-behavioral treatment of anxiety disorders in children: Long-term (6year) follow-up. J Consult Clin Psychol. 2001;69(1):135-41.

22. O'leary EMM, Barrett PM, Fjermestad KW. Cognitive-behavioral family treatment for childhood obsessive-compulsive disorder: a 7-year follow-up study. J Anxiety Disorders. 2009;23(7):973-8.

23. Saavedra LM, Silverman WK, Morgan-Lopez AA, Kurtines WM. Cognitive behavioral treatment for childhood anxiety disorders: long-term effects on anxiety and secondary disorders in young adulthood. J Child Psychol Psychiatry. 2010;51(8):924-34.

24. Kendall PC, Safford S, Flannery-Schroeder E, Webb A. Child anxiety treatment: outcomes in adolescence and impact on substance use and depression at 7.4 year follow- up. J Consult Clin Psychol. 2004;72(2):276-87.

25. Manassis K, Avery D, Butalia S, Mendlowitz S. Cognitive-behavioral therapy in childhood anxiety disorders: functioning in adolescence. Depress Anxiety. 2004;19(4):209-16.

26. Bernstein GA, Bernat DH, Victor AM, Layne AE. School-based interventions for anxious children: 3-, 6-, and 12-month follow-ups. J Am Acad Child Adolesc Psychiatry. 2008:47(9):1039-47.

27. Cobham VE, Dadds MR, Spence SH, McDermott B. Parental anxiety in the treatment of childhood anxiety: a different story three years later. I Clin Child Adolesc Psychology. 2010;39(3):410-20. 